\title{
ANALISA DISTRIBUSI KAPASITAS ALIRAN FLUIDA DI DAERAH PERCABANGAN PADA SISTEM PERPIPAAN
}

\author{
Eswanto $^{1}$, Dian Syahputra ${ }^{2}$ \\ 1,2 Jurusan Teknik Mesin, Fakultas Teknologi Industri, Institut Teknologi Medan \\ 1,2 Jl. Gedung Arca No.52 Medan 20217 Indonesia. Phone \& Fax 061-7347954/7363771 \\ E-mail : eswanto@itm.ac.id ${ }^{1}$
}

\begin{abstract}
Abstrak
Dalam dunia industri dituntut untuk selalu meningkatkan performance dalam meningkatkan produk yang dihasilkan oleh industri, maka dari itu hasil yang diperoleh tersebut tidak terlepas dari mesin atau alat yang menggunakan sistem perpipaan dalam memproses produk yang dihasilkan. Pada instalasi perpipaan banyak dipakai sambungan yang salah satunya berfungsi untuk membelokan arah distribusi aliran fluida, membagi aliran menjadi bercabang sesuai yang diinginkan. Penelitian ini bertujuan untuk mengetahui pengaruh sambungan Tee terhadap koefisien kerugian tekanan akibat pemisahan aliran fluida yang menyebabkan penurunan unjuk kerja dari suatu sistem. Penelitian ini dilakukan secara eksperimen menggunakan fluida air. Data penelitian terdiri atas variabel bebas dan variabel terikat. Pengambilan data dilakukan pada percabangan dengan memvariasikan diameter pipa yaitu $1 / 2$ inchi, $3 / 4$ inchi dan 1 inchi. Hasil penelitian menunjukkan bahwa semakin besar diameter pipa yang digunakan maka nilai koefisien kerugian percabangan Tee semakin kecil yaitu 0,27034 m, 0,17879 m dan $0,0753 \mathrm{~m}$, sehingga nilai debit keluar percabangan meninggkat yaitu 16,8 liter/menit, 17,2 liter/menit dan 17,4 liter/menit. Tingginya bilangan Reynolds yang diperoleh dengan variasi diameter pada seksi uji, mengakibatkan menurunnya koefisien kerugian total, (Re) 43823, 39985, 32719,8 dan $\mathrm{H}_{\text {tot }}$ 6,1667, 17,2, 17,437. Peningkatan bilangan Reynolds (Re) akan berpengaruh terhadap kerugian tekanan (h) pada tiap sambungan.
\end{abstract}

Kata kunci: sambungan Tee, debit, koefisien kerugian, air, percabangan, perpipaan

\begin{abstract}
In the industrialized world are required to review hearts always improving performance boost produced by industry, then the findings from the on lead or not separated from the machine using the tools the process piping systems hearts products in produced. Many of piping installation taken in connection the prayers only serves to review an distribution diverting fluid flow, split flow Being branched accordance desired. Singer study aims to determine the effect connectivity review Tee Against pressure losses due to the separation coefficient fluid flow The causes decrease in performance from the system. Operating singer research conducted experiments using a fluid air. Research data consist of variables differences free and bound variables. Data retrieval is done on with varying the diameter of the pipe branching That is $1 / 2$ inch, 3/4 inch and 1 inch. Research shows that more big diameter pipes which are used then branching coefficient Tee losses small increasingly is $0.2703 \mathrm{~m}$, $0.17879 \mathrm{~m}$ and $0.0753 \mathrm{~m}$, so that the debit value increase branching out Namely 16.8 liter / min, 17, 2 liters / min and 17.4 liters / min. The high Reynolds number variation on lead with diameter test sections, resulting in decreased total loss coefficient, (Re) 43 823, 39 985, 32719.8 And Htot 6.1667, 17.2, 17437. The increase in the Reynolds number (Re) will affect against losses pressure ( $h)$ at every connection.
\end{abstract}

Keyword: Tee connection, discharge, loss coefficients, water, branching, piping

\section{PENDAHULUAN}

Dalam era serba canggih ini, ilmu pengetahuan dan teknologi akan semakin berkembang jika diiringi dengan penelitian, pengujian dan analisa. Dalam bidang engineering, bidang mekanika fluida merupakan salah satu contoh yang perlu untuk mendapat perhatian khusus karena penerapannya luas dengan berbagai aplikasinya, baik di industri skala kecil, menengah maupun industri besar.
Dalam dunia industri dituntut untuk selalu meningkatkan performance dalam meningkatkan produk yang dihasilkan oleh industri, maka dari itu hasil yang diperoleh tersebut tidak terlepas dari mesin atau alat yang menggunakan sistem perpipaan dalam memproses produk yang dihasilkan. Pada instalasi perpipaan banyak dipakai sambungan yang salah satunya berfungsi untuk membelokan arah distribusi aliran fluida, membagi aliran menjadi bercabang sesuai yang diinginkan. 
Penelitian ini bertujuan untuk mengetahui pengaruh sambungan Tee terhadap koefisien kerugian tekanan akibat pemisahan aliran fluida yang menyebabkan penurunan unjuk kerja dari suatu sistem.

\section{TINJAUAN PUSTAKA}

Penerapan pinsip-prinsip dalam bidang mekanika fluida dapat dijumpai pada bidang industri. Misalnya saja pada Perusahaan Air Minum (PAM) dan Perusahaan Tambang Minyak Negara (PERTAMINA). Rangkaian pada sistem perpipaan tersebut didesain sedemikian rupa sehingga mampu memenuhi segala kebutuhan akan pendistribusian fluida sesuai dengan kebutuhan proses tersebut. Pada instalasi perpipaan, banyak dipakai sambungan yang berfungsi untuk membelokan maupun membagi aliran menjadi bercabang. Pemisahan aliran fluida pada percabangan merupakan hal yang tidak dapat dihindari sehingga dampaknya akan dapat menurunkan unjuk kerja dari suatu sistem. Oleh karena itu efesiensi pendistribusian dalam industri harus diperhatikan. Dengan efesiensi yang baik, maka biaya produksi dapat ditekan sehingga harga jual produk atau barang tersebut lebih kompetitif.

Penelitian aliran dalam pipa pertama dilakukan oleh Julius Weisbach (1850) yang meneliti rugi pada hulu pipa, kemudian dilanjutkan oleh Henry Darcy (1857) dengan melakukan ekperimen aliran pipa dan mengungkap efek kekasaran pada hambatan pipa yang dikenal dengan persamaan Darcy-Weisbach. Apabila fluida mengalir melalui suatu percabangan maka akan terjadi separasi yang mengakibatkan terjadinya kerugian tekan. Kerugian head pada setiap cabang boleh dianggap sepenuhnya terjadi akibat gesekan, atau rugi akibat katup dan perlengkapan pipa. Kalau kerugian head dan totalnya (head losses) diketahui, relatif cukup mudah untuk mencari masing-masing Q1 dan menjumlahkannya. Soal sebaliknya, jika laju aliran totalnya Q yang diketahui, di perlukan pengulangan yang lumayan jumlahnya untuk menentukan bagaimana aliran total ini terbagi kedalam ketiga cabang pipa tersebut.

Bidang mekanika fluida berhubungan dengan perilaku fluida pada keadan diam dan bergerak. Pada logikanya, fluida merupakan suatu substansi yang terdeformasi secara berkelanjutan yang diakibatkan oleh adanya tegangan geser walaupun seberapa kecilnya nilai dari tegangan geser tersebut. Fluida terdiri dari fasa cair, gas dan padat. Perbedaan antara fluida cair dengan fluida padat sangat jelas yakni jika dibandingkan reaksi fisik dari keduanya. Fluida padat memiliki keterbatasan reaksi deformasi ketika menerima gaya geser, yakni deformasi tidak akan berkelanjutan seiring perubahan terhadap waktu.Aliran fluida dapat dibedakan atas 3 jenis yaitu aliran laminar, aliran transisi, dan aliran turbulen. Jenis aliran ini didapat dari hasil eksperimen yang dilakukan oleh Osborne Reynold tahun 1883 yang mengklasifikasikan aliran menjadi 3 jenis. Jika air mengalir melalui sebuah pipa berdiameter d dengan kecepatan rata-rata $\mathrm{V}$ maka dapat diketahui jenis aliran yang terjadi. Berdasarkan eksperimen tersebut maka didapatkan bilangan Reynold dimana bilangan ini tergantung pada kecepatan fluida, kerapatan, viskositas, dan diameter.

Aliran fluida yang melalui pipa akan selalu mengalami kerugian head. Hal ini disebabkan oleh gesekan yang terjadi antara fluida dengan dinding pipa atau perubahan kecepatan yang dialami oleh aliran fluida (kerugian kecil). Kerugian head akibat gesekan dapat dihitung dengan menggunakan rumus berikut,yaitu:

1. Persamaan Darcy- Weisbach yaitu:

$$
\mathrm{hf}=\mathrm{f} \frac{l v^{2}}{d 2 g}
$$

Dimana :

$\mathrm{hf}=$ kerugian head karena gesekan (m)

$\mathrm{f}=$ faktor gesekan (diagram Moody)

$\mathrm{d}=$ diameter pipa $(\mathrm{m})$

$\mathrm{L}=$ panjang pipa $(\mathrm{m})$

$\mathrm{v}=$ kecepatan aliran fluida dalam pipa $(\mathrm{m} / \mathrm{s})$,

$\mathrm{g}=$ percepatan gravitasi $(\mathrm{m} / \mathrm{s} 2)$.

Pada zat cair diam gaya-gaya yang bekerja dapat dihitung dengan mudah karena dalam hidrostatika hanya bekerja gaya tekan sederhana. Faktor-faktor yang diperhitungkan tidak hanya kecepatan dan arah partikel, tetapi juga pengaruh kekentalan yang menyebabkan gesekan antara partikel-partikel zat cair dengan dinding batas. Persamaan energi yang menggambarkan gerak partikel diturunkan dengan persamaan gerak. Persamaan energi merupakan salah satu persamaan dasar untuk menyelesaikan masalah yang ada dalam hidrolika. Dimana dari hukum kekekalan energi menyatakan energi total fluida pada satu titik sama dengan energi total fluida pada titik dua.

Dari kondisi diatas tersebut diturunkan suatu persamaan yang dikenal dengan persamaan bernoulli (evett, 1987) yaitu:

$\frac{P_{1}}{P}+\frac{V_{1}^{2}}{2}+g \cdot z_{1}=\frac{P_{2}}{P}+\frac{V_{2}^{2}}{2}+g \cdot z_{2}=$ tetap

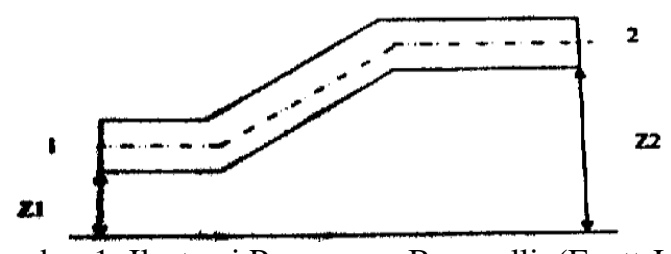

Gambar 1. Ilustrasi Persamaan Bernoulli, (Evett Jack and Cheng Liu, 1987).

Seperti yang telah diuraikan sebelumnya, bahwa permasalahan aliran fluida dalam pipa dapat diselesaikan dengan menggunakan persamaan Bernoulli, persamaan Darcy dan diagram Moody. Penggunaan rumus empiris juga dapat digunakan untuk menyelesaikan permasalahan aliran.

Menurut Ari Dwiyantoro (2004), dengan adanya percabangan pada aliran incompressibel fluid dapat 
menyebabkan terganggunya aliran akibat separasi yang menyebabkan kerugian dari tekanan total. Tumbukan yang terjadi pada daerah percabangan pipa mengakibatkan proses aliran menjadi turbulen. sehingga koefisien gesek menjadi tinggi dan menyebabkan penurunan tekanan yang akan berpengaruh pada energi yang dibutuhkan oleh pompa sebagai alat penyuplai pendistribusian fluida.

Salah satu gangguan atau hambatan yang sering terjadi pada saluran pipa adalah kehilangan tinggi tekanan air yang diakibat adanya gesekan/mayor losses dan minor losses (Kodoatie, 2002) seperti adanya perubahan arah, belokan dan perubahan penampang pipa.

Dalam penelitiannya, Costa (2006), variasi tekanan, kecepatan rata-rata dan kecepatan turbulen yang terjadi pada aliran air di dalam bentuk sudut tajam dan sudut bundar pada sambungan Tee $90^{\circ}$ yang diukur pada rasio aliran $50 \%$ dengan bilangan Reynolds 32.000

Untuk rugi tekanan (Head loss) pada pipa bengkok (Study of the Separated and Total Losses in Bend) telah diteliti oleh (Abubaker et-all, 2003): Bahwa kerugian gesek mayor mempunyai pengaruh signifikan pada kerugian gesekan total ketika perbandingan bend curvatur radius (r).

Menurut Krist (2007), kehilangan tekanan air pada pipa-pipa bengkok dan berbelok dan pipa siku-siku (kehilangan oleh belokan-belokan) dapat menimbulkan kehilangan-kehilangan karena berubahnya arah. Kehilangan karena perubahan arah tercakup dalam

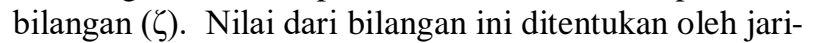
jari bengkokan (r) dari sudut bengkokan $(\delta)$. Secara normal nilai $\zeta$ yang akan menjadi kecil jika hari-jari rb jadi lebih besar adalah tergantung dari pada perbandingan jari-jari bengkokan atau diameter dalam pipa.

Sedangkan terkait dengan turbulensi yang terjadi di dalam pipa Setyo (2006) menjelaskan bahwa aliran turbulen mempunyai koefisien gesek yang lebih tinggi dibandingkan dengan aliran laminar, tingginya koefisien gesek berpengaruh secara langsung pada besarnya penurunan tekanan dan besarnya energi yang di perlukan untuk mengalirkan fluida

\section{METODE}

Untuk memperoleh data penelitian, maka dilakukan dengan metode eksperimen. Dalam eksperimen yang dilakukan untuk pengambilan data yang yaitu secara destriktif. Jumlah parameter dapat dibatasi sehingga dapat menghemat biaya dan waktu pelaksanaan. Proses ekperimen dilakukan untuk menganalisa kapasitas aliran di percabangan pipa. Hal ini dilakukan guna melihat kapasitas aliran fluida akibat percabangan pipa yang direncanakan. Dalam proses penelitian ini dilakukan dengan alat uji yang dirancang sedemikian dan digunakan untuk menguji guna memperoleh data terkait dengan tema riset ini.

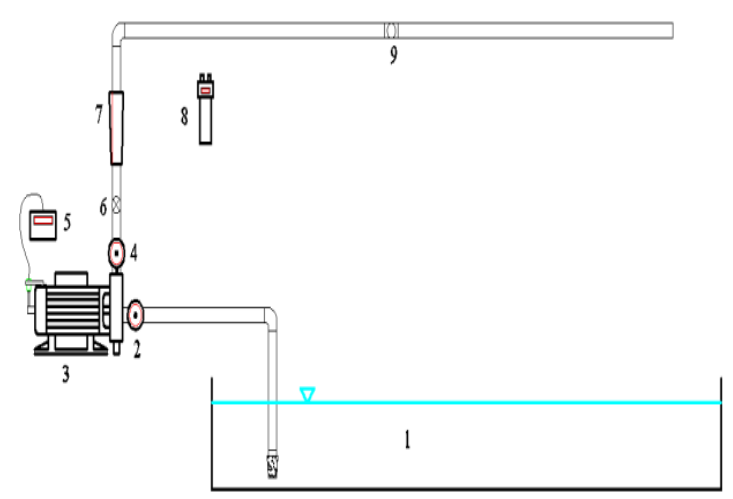

Gambar. 2 Set up alat uji

Keterangan :

1. Bak penampungan air.

2. Pressure guage.

3. Pompa sentripugal.

4. Pressure Guage.

5. TachoMeter.

6. Glove Valve.

7. Flowmeter Air.

8. Manometer.

9. Percabangan Tee.

Diagram Alur Penelitian :

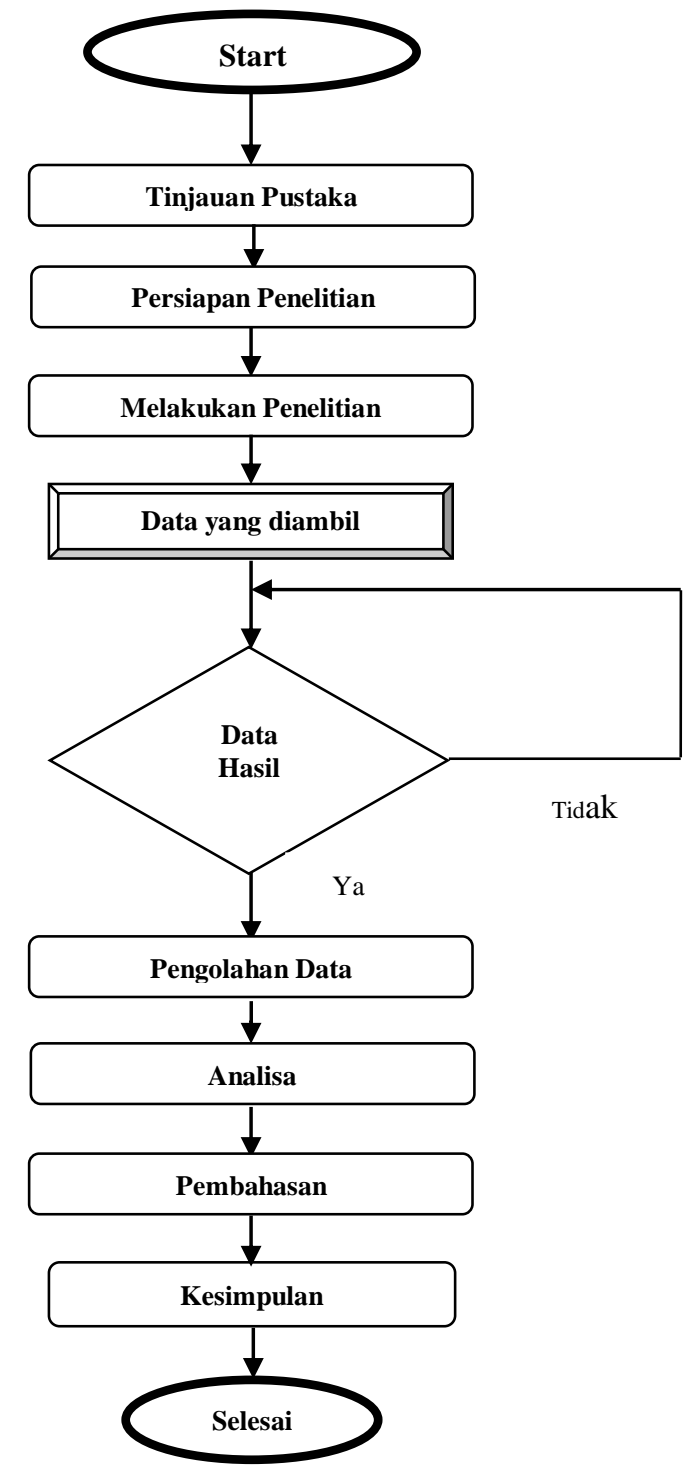


IV. HASIL DAN PEMBAHASAN

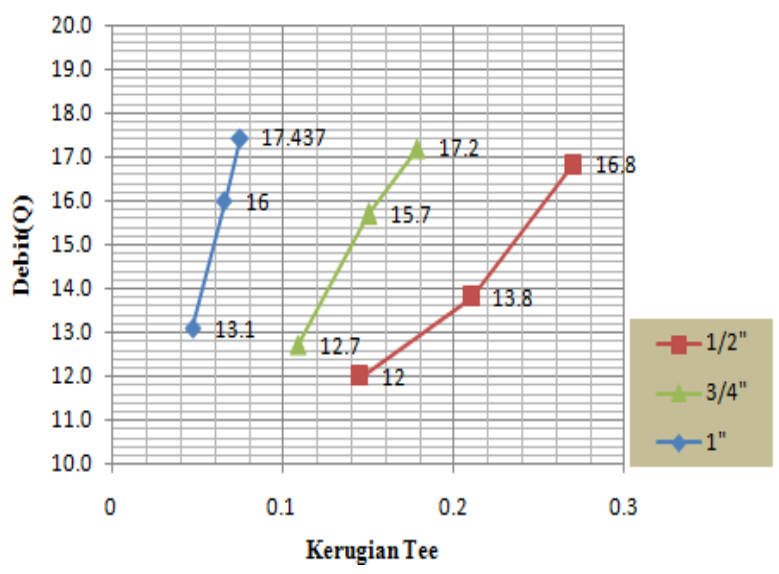

Gambar 3. Grafik hubungan percabangan Tee terhadap debit aliran pada variasi diameter pipa.

Berdasarkan hasil pengujian dan pengukuran laju aliran pada pipa cabang yang diukur dengan menggunakan Flow Meter serta pipa keluaran, maka untuk memperoleh grafik hasil pengujian harus dihitung kemudian hasilnya dibuat dalam sebuah grafik hasil. Dalam analisa hasil pengukuran ini yaitu untuk percabangan Tee dengan diameter pipa $1 / 2$ inchi, $3 / 4$ inchi dan 1 inchi. Dari gambar 3 diatas terlihat bahwa dengan variasi diameter pipa, kerugian percabangan Tee pada diameter pipa 1 inch memiliki nilai yang lebih rendah dibandingkan dengan pipa $3 / 4$ inch dan $1 / 2$ yaitu antara $0,0753,0,17879$ dan 0,27034 . Nilai kerugian ini berbanding terbalik dengan debit keluar percabangan Tee.Nilai debit tertinggi pada diameter pipa 1 inch yaitu 17,437 . Adapun dari grafik diatas dapat kita ketahui bahwa hal yang mendasar yang menyebabkan hubungan berbanding terbalik adalah kecepatan alirannya.

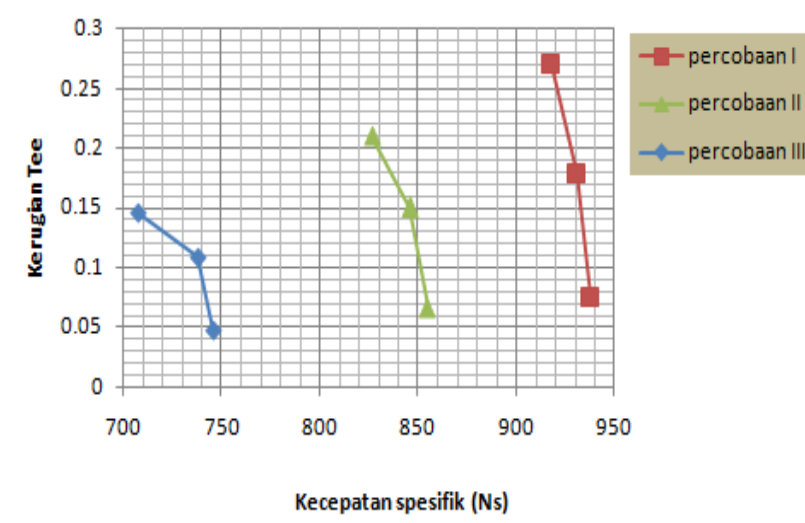

Gambar 4. Grafik hubungan antara kerugian percabangan Tee dengan kecepatan spesifik.

Pada dasarnya, besarnya nilai kerugian percabangan berpengaruh terhadap menurunnya nilai kecepatan spesifik. Gambar 4 garfik di atas telah jelas memperlihatkan hubungan tersebut, dimana terlihat kondisinya berbanding terbalik yaitu semakin besar kecepatan spesifiknya maka kerugian tee yang dihasilkan semakin menurun. Kondisi tersebut banyak hal yang mempengaruhinya diantaranya adalah semakin kecil gesekan yang ditimbulkan pada daerah di dinding pipa akibat tingginya kecepatan aliran. Adapun nilai tertinggi kecepatan spesifik yaitu 938 dengan diameter pipa 1 inch dan nilai kerugian percabangan 0,0753 .

Sedangkan nilai terendah tejadi pada pipa $1 \frac{1}{2}$ inchi yaitu sebesar 918 Rpm dengan nilai kerugian percabangan $0,27034 \mathrm{~m}$.

Pada gambar 5 adalah grafik hubungan antara total head terhadap efesiensi dengan variasi diameter pipa. Total head pompa dipengaruhi oleh besarnya kerugiankerugian pada rangkaian pipa dan juga tekanan pada pompa yang masuk dan tekanan keluar pompa. Sehingga head total pompa mempengaruhi besarnya efisiensi pompa dengan nilai sebagai berikut, dengan Total head 6,1667 m didapat $\eta p$ 58,5\%, dan Total head 6,506 m, $\eta_{\mathrm{p}} 57 \%$, sedangkan pada total head 7,0504 m efesiensinya, $\eta_{\mathrm{p}} 53,5 \%$. Dari hasil tersebut didapat kesimpulan bahwa semakin besar total head pompa maka semakin kecil efisiensi pompa yang dihasilkan.

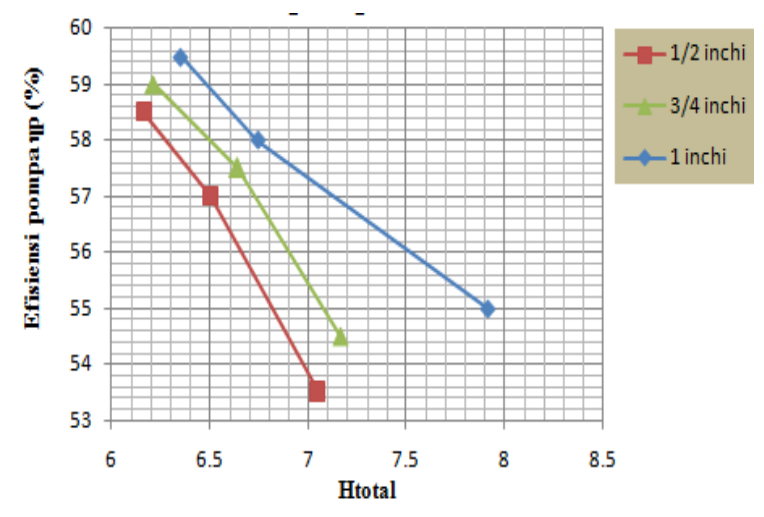

Gambar 5. Grafik hubungan total head terhadap efisiensi pompa dengan variasi diameter pipa.

\section{PENUTUP}

\section{Kesimpulan}

Berdasarkan hasil penelitian yang telah dilakukan terhadap percabangan aliran dengan diameter $(1 / 2$ inchi, 3/4 inchi, 1 inchi) maka dapat diperoleh kesimpulan, yaitu: Nilai kerugian percabangan memberikan pengaruh terhadap kenaikan debit. Semakin kecil luas penampang maka kerugiannya akan semakin besar. Koefisien kerugian percabangan untuk diameter pipa $1 / 2$ inchi, $3 / 4$ inchi dan 1 inchi masing-masing yaitu 0.27034 $\mathrm{m}, 0.17879 \mathrm{~m}$ dan $0.0753 \mathrm{~m}$ dengan debit $16.833 \mathrm{Lpm}$, 17.2 Lpm dan 17.437 Lpm. Sedangkan head total pompa mempengaruhi besarnya efisiensi pompa. Untuk total head $6,1667 \mathrm{~m}$ maka $\eta_{\mathrm{p}} 58,5 \%$, total head 6,506 $\mathrm{m}$ maka $\eta_{\mathrm{p}} 57 \%$ dan total head 7,0504 m maka $\eta_{\mathrm{p}} 53,5$ $\%$. Dari hasil perhitungan didapat kesimpulan bahwa semakin besar total head pompa maka semakin kecil efisiensi pompanya. 


\section{Saran}

Dalam pengembangan penelitian selanjutnya perlu kiranya divariasikan bentuk percabangan ataupun bentuk variasi sudut yang sesuai untuk meningkatkan performa dalam sistem percabangan pipa.

\section{VI.DAFTAR PUSTAKA}

[1] Arip Dwiyantoro, B., Studi Ekperimental Tentang pengaruh Protituding (Tonjolan) pada Pipa Lurus Bercabang 450 dan 600 terhadap Distribusi Kecepatan dan Tekanan Aliran, ITS, Surabaya, 2004.

[2] Abubaker A. Salem, Saib A. Yousif \& Yasser F. Nassar, Study of the Separated and Total losses in Bends, Proceedings of the International Conference on Fluid and Thermal Energy Conversion, Bali, Indonesia, 2003.

[3] Costa N.P., Mania.R, 2006. Edge Effects on the Flow Characteristics in a $90 \mathrm{deg}$ Tee Junction, Journal of Fluids Engineering, Vol. 128, pp. 1204:1217,(Http://link.aip.org/link/?JFEGA4/128/ 1204), diakses 12 Maret 2007.

[4] Darcy H., Recherches Expérimentales Relatives au Mouvement de l'Eau dans les Tuyaux [Experimental Research on the Movement of Water in Pipes]. Mallet-Bachelier, Paris, Publishing, 1857.

[5] E. Jack and C. Liu, "Fundamentals of Fluid Mechanics", Mcgraw-Hill College, 1987

[6] J. Weisbach "Viscous Flow in Ducts Reynolds number regimes" german,journal Publishing, 1850.

[7] Kodoatie. Robert., Hidrolika Terapan, Aliran Pada Saluran Terbuka dan Pipa. : Andi Oftset, Yogyakarla, 2002.

[8] Krist. Thomas., Hitlrauliku ('ferjemahan Dittes Ginting). Jakafta: Erlangga, 1991.

[9] Maryono Agus, Hidrolika Terapan, Pradnya Paramita, Jakarta, 2003.

[10] Setyo Indartono, Y., Meredam Turbulensi Membuat Air Mengalir (jauh) lebih cepat, 2006 (Http://BERITA\%20IPTEK\%20ONLINE\%20\%M eredam\%20turbulensi) 